\title{
Histochemical studies on the role of pantothenic acid on radiation damage of the kidney
}

\author{
*Omaima, S.Eissa and **Ashraf, M.Moustafa \\ * National Centre for Radiation Research and Technology, \\ ** Histology Dept., Faculty of Medicine, AL-Azhar University, Cairo, Egypt
}

\begin{abstract}
The present study was designed to evaluate effect of pantothenic acid to gamma irradiated rats. Female albino rats (120-150gm) were subjected to (5 Gy) whole body ${ }^{137} \mathrm{Cs}$ gamma irradiation. Fresh kidney specimens were obtained after 1 and 4 weeks of treatment. Frozen sections were prepared for histochemical study for localization of both acid, alkaline phosphatases and succinic dehydrogenase enzymes. The enzymatic activity was quantitatively evaluated and statistically analyzed. The obtained results showed significant decrease in both alkaline phosphatase and succinic dehydrogenase enzymes activity while the acid phosphatase enzyme activity was significantly increased in comparison to the control group after one week, while after four weeks the activity of both acid and alkaline phosphatase were significantly increased, while the enzymatic activity of succinic dehydrogenase decrease.

Pantothenic acid treatment ( $22 \mathrm{mg} / \mathrm{kg}$ body weight / day for 6 days) after half hour of radiation showed marked improvement of the radiation induced changes in the activity of measured enzymes.

Finally it could be concluded that pantothenic acid could be of value in improving the radiation injury on the kidney.
\end{abstract}

\section{Introduction}

Although our life style provides us with many advantages, the utilization of oxygen by cells results in the production of highly reactive free radical products. Uncontrolled reactive free radical can results in damage to cell structures and functions. Free radicals are implicated in the progressive accumulation of tissue damage, which in some individuals may eventually be recognized as disease (Packer, 1991). The toxic role of free radicals has been appreciated in several forms of cellular injury and in a variety of disease states (Boner et al., 1988).
Antioxidant defenses that protect the body from free radical damage includes the enzyme superoxide dismutase, catalase and glutathione peroxidase and several micronutrients such as antioxidant vitamins (Oski, 1980).

Pantothenic acid is antipellagra vitamin essential to many animals for growth and health. It is widely distributed in nature, appreciable amounts are found in the liver and some microorganisms. Bound forms of pantothenic acid, such as coenzyme A and 4'-phosphopantetheine, play an 


\section{Histochemical studies on the role of pantothenic}

important role in various metabolic processes, degradation (Shimizu, 1999).

Pantothenic acid is a precursor of coenzyme A, which is a cofactor required for oxidative metabolism of carbohydrates, gluconeogenesis synthe sis and breakdown of fatty acids, and steroid synthesis (Ganong, 1995)

Pantothenic acid should be particularly useful in producing a long and healthy life due to their recently discovered capacity as building blocks for the vitaletheine modulators and cofactors for associated enzymatic receptors.

Exposure to high doses of ionizing radiation is associated with physiopathological changes. These changes differ in their severity according to the radiosensitivity and responses of individual organs and tissues (Yarmonenko, 1988).

It is well established that most of the physiological activities in the animal body were disturbed after exposure to ionizing radiation. These disturbances are either due to the direct harmful effect of irradiation on the biological systems or indirect effect of free radicals liberated in the body after irradiation (Hagen, 1989). Activities of most lysomal enzymes increased after exposure to ionizing radiation (AbouSafi, 1998). Alkaline phosphatase showed to be sensitive to irradiation (Roushdy et al., 1984).

\section{Material and Methods}

Forty-eight female albino rats weighing from 120-150 gm were used. Animals were housed in cages under good ventilation condition and adequate stable standard diet.

Irradiation was performed by Gamma Cell-40 (Cesium-37) source belonging to the National Center for Radiation Research and Technology
(NCRRT). This cesium source offers a dose rate $1.367 \mathrm{rad} / \mathrm{sec}$.

Rats were treated with pantothenic acid $(22 \mathrm{mg} / \mathrm{kg}$ body weight /day) $1 / 2 \mathrm{hr}$. after whole body gamma irradiation at the dose level $5 \mathrm{~Gy}$.

The animals were divided into 4 groups each of them 12 rats.

\section{Group I: Control rats.}

Group II: Irradiated group expo sed to a single dose of gamma rays at the dose level 5 Gy.

Group III: Treated group, they are received pantothenic acid orally in a dose of $(22 \mathrm{mg} / \mathrm{kg}$ body weight/ day ) for 6 days.

Group IV Irradiated and treated group. Rats exposed to gamma rays as in group I and after half hour of exposure received pantothenic acid as in group III.

The animals were scarified one and four weeks after treatment, fresh kidney specimens were obtained, frozen sections ( 8 um thick) were prepared for histochemical study.

Different histochemical techni ques were used for localization of the activity of enzymes including .

1. Gamori Techniques for acid phosphatase enzyme (Pearse, 1975).

2. Modified Gamori Techniques for alkaline phosphatase enzyme (Pearse, 1975).

3. Nachla's Technique for succinic dehydrogenase enzyme (Nachla's et al., 1957 and Pearse, 1975).

Quantitative analyses were carried out to evaluate the enzymatic reaction using computer image analyzing system. The system is supplied by research microscope and colored video camera. Estimation of the optical density (0:0) was done. The obtained results were statistically analyzed. 


\section{Omaima, S.Eissa et al}

\section{RESULTS}

\section{Renal changes:}

1 - Changes in the activity of the acid phosphatase enzyme in the renal tissues

After one week of the treatment there is a significant decrease in the enzyme activity in treated and irradiated treated groups while the activity of enzyme was significantly increased in the irradiated group when compared to the control group (Table 1).

After four weeks of the treatment there is a significant decrease in the activity of the enzyme in all groups when com pared to the control group(Table 3 ).

\section{Changes in blood vessels}

After one week of the treatment there is significant increase in the enzymatic activity in all groups when compared with those in the control group (Table 2).

After four weeks there is significant decrease in the activity of the enzyme in irradiated and irradiated treated groups while a significant increase in the enzyme activity of treated group when compared with that in the control group (Table 4).

2- changes in the alkaline phosphatase enzyme activity in the renal tissue.

After one week there is significant decrease in enzymatic activity in the irradiated and treated groups when compared to those in the control group, Significant increase in the enzymatic activity was observed in the irradiated treated group when compared with those in control group (Table 1).

After four weeks there is significant increase in enzymatic activity of treated irradiated group but both irradiated and treated groups, showed significant decreased in the enzymatic activity. (Table 3).

\section{Changes in the blood vessels}

After one and four weeks of the treatment there was a significant decreased in the enzymatic activity of all the groups when compared with the control one (Table 2, 4).

3 - Changes in the succinic dehydrogenase enzyme activityin renal tissue

Significant increase in the enzymatic activity of treated and irradiated treated groups, when compared with the control group after one week, while a significant decrease in the activity of enzyme in irradiated group (Table 1). After four weeks, there was significant increase in the enzymatic activity all groups when compared with those in the control one (Table 3).

\section{Changes in the blood vessels}

After one week there was significant increased in enzymatic activity in both treated and irradiated treated groups while a significant decrease in the enzymatic activity was noticed in the irradiated group when compared with those in the control group.

After four weeks there was significant increased in the activity of the enzyme of the irradiated and irradiated treated groups and no change were noticed in the treated group when compared to those in the control one

(Table 4).

\section{DISCUSSION}

It is known that, over exposure to ionizing radiation may cause systemic injuries include damage to blood forming organs, hormonal imba lance, and disturbance of enzymatic activities.

Quantitative histochemistry opens a new field of research by meas uring the metabolic and enzymatic 


\section{Histochemical studies on the role of pantothenic}

activity in tissues and cell so better understanding of the possible functional changes. The kidney is one of the highly active and vital organ, which can be affected by physical factors as radiation. Our results showed significant changes in the activity of acid phosphatase, alkaline phosphatase and succinic dehydrogenase enzymes in kidney subjected to radiation hazard.

The changes in the activity of acid phosphatase enzyme was highly related to the radiation dose (Lee et al., 1994). The present study showed significant increase in acid phosphatase enzyme activity in the renal tissue either cells or blood vessels of irradiated rats. These results are in agreement with Rene et al. (1971; Zyss and Kaszezynska (1972), Shah and Gadhia (1977), Snyder and Ekeland (1978). Khamis and Roushdy (1991), who observed an increase in the acid phosphatase enzyme activity one week post irradiated. Our results obtained after 4 weeks from exposure are with those finding of Kotb et al. (1991); Verma et al., (1994), and Bahig and Hassanin (1994) who observed that the activity of the enzyme was increased one week from exposure and followed by gradual decrease in the activity of the enzyme after irradiation Rubini and Casarett (1968), observed pronounced vascular damage following renal irradiation. Radiation damage is characterized by a progressive reduction in renal function with little evidence for recovery (Stewart et al., 1986).

Alkaline phosphatase enzyme is a membrane bound glycoprotein is used as a marker enzyme for the plasma membrane and one of its most interesting aspects is easily inducible in response to various stimuli (Knolwes et al., 1979). The biological function of this enzyme was uncertain, but it has possible role in cellular transport
(Russel et al., 1972), as a regulator of cell metabolism (Huang et al., 1976). Its activity had been found in the intercellular as well as on the surface membrane (Seetharam et al., 1977).

Our results showed significant decrease in the activity of alkaline phosphatase enzyme one week post irradiation in the renal cellular structures and blood vessels of the kidney of rats exposed to (5 Gy) gamma radiation which presist to four weeks post exposure.

The activity of this enzyme significantly decrease at one week post irradiation while after four weeks the activity increased. The decrease in that enzyme activity observed in the present study is similar to different pathological condition. Thus, the enzyme activity was reduced during starvation (Moussa et al., 1987), in case of mercury intoxification (Sastry and Rao, 1981), after insecticide treatment (Moussa et al., 1987) and in antibiotic treatment (El-Beih et al., 1993 and 1998).

The various changes in the activity of acid, alkaline phosphatases and succinic dehydrogenase enzyme were observed in this study related to the effect of gamma irradiation on the cell membrane permeability or the integrity of the cell membrane resulting in serious disturbances of the equilibrium, existing between the intracellular and extracellular fluids (Hashish et al., 1973).

Protection from gamma radiation by chemical means, still of interest of many radiobiologists, trying to acheive less toxic substance with maximum protecting action against radiation effects.

Vitamins are one of the several pharmacological compound that could act as radioprotectors or curative to damage effects of radiation exposure, (Kawasaki and Sakarai, 1969 and 


\section{Omaima, S.Eissa et al}

Kafafy, 2000).

Pantothenic acid is a water soluble B vitamin that cannot be stored in the body and acts as an essential component in the production of coenzyme A, a vital catalyst which is required for the conversion of carbohydrates, fats and protein into energy. Pantothenic acid is also referred as an antistress vitamin due to its vital role in the formation of various adrenal hormones, steroids, and cortisone as well as contributing to the production of important brain neurotransmitters such as acetylcholine . Pantothenic acid also supports the normal functioning of the gastrointestinal tract and is required for the production of cholesterol, bile, vitamin $\mathrm{D}$, red blood cells and antibodies (Schlosser, 1989).

Our results obtained showed that administration of pantothenic acid after radiation exposure induced significant improvement in the enzymatic activity measured in the different renal structures and blood vesselsunder the effect of radiation exposure through increasing the immunity of the body (Kishore et al., 1976). The modifying role of pantothenic acid could be attributed to its action in scavenging free radicals produced after radiation exposure and it have a redox reactions (Moorthy and Hayon, 1977 and Styshenkov et al., 1996 and 1999).

\section{REFERENCES}

1. Abou-Safi, H.M.(1998): Haematological and physiological impairment of irradiation during estrus cycle in rats and role of combined treatment with vitamins A and B Group. Egypt. J.Med. Sci., 19, 157.

2. Bahig, M.E. and Hassanin, M.M. (1994): Effect of cyolane on carbohydrate and lipid metabolism in rat. Proceedings of the Second Arab Conference on the Peaceful Uses of Atomic Energy. Part II: A and B. Oct. 1995, 1199 p. 1181.

3. Broner, C.W.; Shenep, J.L.; Stidham, G.L.; Stakes, D.C. and Hildner, W.K.(1988): Effect of scavenger of oxygen-derived free radicals on mortality in mice. Care. Med., 16(9):816-848.

4. El-Beih, Z.M.; Amer, M.A. and Elew, F.H.(1993): Histoenzymology alterations in the succinic dehydrogenase activity in the cells of mice administered erythromycin. Proc. Egypt. Acad. Sci., 43: 113-121.

5. El-Beih, Z.M.; Amer, M.A. and Ateia, M.A. (1998): Effect of narcotics on the mitochondria and succinic dehydrogenase activity of the intestinal epithelial cells of mammals. Egypt. J.Histol., 2(2): 281-292.

6. Ganong, W.F. (1995): Review of Medical Physiology. 17th Ed. A Long Medical Book.

7. Hagen, U. (1989): Biochemical aspects of radiation biology. Experientia, 45, 7.8.

8. Hashish, S.E.; Ibrahim, H.A. and Wadie, A.F.(1973): Arab J.of Nuclear Sci. and Applic., 6: 101109.

9. Huang, K.; Robinson, J.C. and Chon, J.Y. (1976): Phosphoprotein phosphatase activity associated with human placental alkaline phosphatase. Biochem. Biophys. Res. Commun., 70: 186-192.

10. Kafafy, Y.A. (2000): Protective effect of cystcien and vitamine $\mathrm{E}$ on gamma irradiation injury in rats. Egypt. J.Rad. Sci. Applic., 13,2,17.

11. Kawasaki, S. and Sakarai, K. (1969): Effect of some drugs on recovery from radiation damage. Nippon Igaku Hoshasen Gakkai 


\section{Histochemical studies on the role of pantothenic}

Zasshi, 28: 1375-1378.

12. Khamis, F.I. and Roushdy, M.H. (1991): Synergistic radioprotective action of imidazole and serotonin on serum and liver enzymes in rats. Arab J.of Nuclear Sciences and Applications. Vol 24(1): 19-36.

13. Kishore, K.; Moorthy, P.N. and Rao, K.N. (1976): Study of radiation damage and protection of some vitamins in aqueous media. Proceedings of the Indian National Science Academy, Part B 42(4-5) 238-249.

14. Knowles, D.M.; Hoffman, H.T.; Ferraini M. and Kunkel, H.G. (1979): Acid naphthyl acetate esterase activity in human neoplastic lymphoid cells. Am.J.Phothol., 96:257-278.

15. Kotb, M.A.; Abd El-Mawla, A.; El-Khatib, A. and Ramadan, M.I. (1991): Effect of whole body irradiation by fast neutrons on mouse tissues. Pt.1. Activity of acid phosphatase and succinic dehydrogenase in kidney, lung and liver. Isotopenpraxis, 27(3): 97100.

16. Lee, K.S.; Cheon, K.L.; Kim, K.C.; Kim, J.K.; Kim, I.K. and Park, H.K. (1994): Development of technology for biological dosimetry. A study on the radiation and environmental safety. Jul., 85.

17. Moorthy, P.N. and Hayon, E. (1977): One electron redox reactions of water soluble vitamins. J.Org. Chem. 42(5): 879-885.

18. Moussa, T.A.; El-Beih, Z.M. and Amer, M.A. (1987): Changes in the acid phosphatase and succinic dehydrogenase activities in mammalian gastric glandular cells induced by insecticide intoxication and stravation. Egypt. J. Histol., 10(1): 129-138.

19. Nachlas, M.; Tsou, K.; DeSouza,
E.; Change, C. and Seligman, A. (1957): Cytochemical demonstration of succinic dehydrogenase by use of new $p$ nitrophyl substituted ditetrazol. J. Histochem. Cytochem., 6: 420-436.

20. Oski, F.A.(1980): Vitamins a radical defense. New Engl. J. Med., 303: 454-5.

21. Packer, L.(1991): Protective role of vitamins in biological system. Am. J. Clin. Nutr., 53: 1050S-55S.

22. Pearse, A.G. (1975): Histochemistry Theoretical and Applied, Vol. 3 rd ed. P150, Williams and Wilkins Co., Baltimare, London and New York.

23. Rene, A. A.; John, H. D. and Joseph, L. P. (1971): Radiation induced ultrastructural and biochemical changes in lysosomes. Lab.Invest., 25(3): 230-239.

24. Roushdy, H. M.; Ibrahim, H. A. and Edrees, G.M.F. (1984): Spleen homogenate for biological treatment of radiation induced disorders in the activity of certain serum and liver enzymes. Egypt. J.Rad. Sci. Appli., 1, 107.

25. Russel, R.G.G.; Honod, A.; Bonjour J.P. and Fleisch, $\mathrm{H}$. (1972): Relation between alkaline phosphatase and ca+2 ATPase in calcium transport. Nature, 240: 126-127.

26. Rubin, P. and Casarett, G.W. (1968): In:" Clinical radiation pathology".1st ed. Volume II, W.B. Saunders Company, Philadelphia, London, Toronto.

27. Sastry, K.V. and Rao, D.R. (1981): Enzymological and biochemical changes produced by mercuric in a teleost fish, Channa punctatus. Toxicol. Lett., 9(4): 421326.

28. Schlosser, C.A.S. (1989): The effect of alterations in total 


\section{Omaima, S.Eissa et al}

coenzyme A on metabolic pathways in the liver and heart. Philadelphia, (USA). Temple Univ., p.225.

29. Seetharam, B.; Yeh, K.; Moog, F. and Alpers, D.H. (1977): Development of intestinal brush border membrane protein in rat. Biochem. Biophys. Acta., 470-424..

30. Shah, V.C. and Gadhia, P.K.(1977): Effects of sublethal doses of gamma irradiation on phosphatases and succinate dehydrogenase levels in liver, kidney and spleen of pigeon. Indian J.Exp. Bio., 15: 1216-1217.

31. Shimizu, S. (1999): Pantothenic acid. Nippon Rinsho, 57(10): 2218.

32. Slyshenkov, V.S.; Moiseenok, A.G. and Wojtezak, L. (1996): Noxious effects of oxygen reactive species on energy coupling process in Erlich ascites tumor mitochondria and the protection by pantothenic acid. Free radical. Biol. Med. 20(6): 239.

33. Slyshenkov, V.S.; Omelyachik, S.N. Moiseenok, A.G. Petushok, N.E. and Wojtezak, L. (1999): Protection by pantothenic and beta carotene against liver damage
34. produced by low dose gamma radiation. Acta. Biochim. Pol. 46(2): 239.

35. Snyder, S. L. and Ekeland, S. K. (1978): Radiation induced alterations of lysosomal hydrolases in rat spleen homogenates. Radiat. Res., 75: 91-97.

36. Stewart, F.A.; Lebesque, J.V. and Hart, G.A. (1986): Progressive development of radiation damage in mouse kidneys and the conseq uences for irradiation tolerance. Int, J.Rad. Oncol. Biol., 53: 405.

37. Verma, C.L.; Purohit, R.K.; Srivastava, M. and Gupta, M.L. (1994): Radiation induced changes in the kidney of passer domesticus linn. J.of Med. Physics, 19(1): 3538.

38. Yarmonenko, S.P. (1998): In "radiobiology of human and animals". Mir. Publisher, Moscow, 33.

39. Zyss, R. and Kaszezynska, M. (1972): The lysosomal system of liver cells in rats following a radiation dose of 100 rat. Acta. Med. Pol., 13(2): 177-192. 


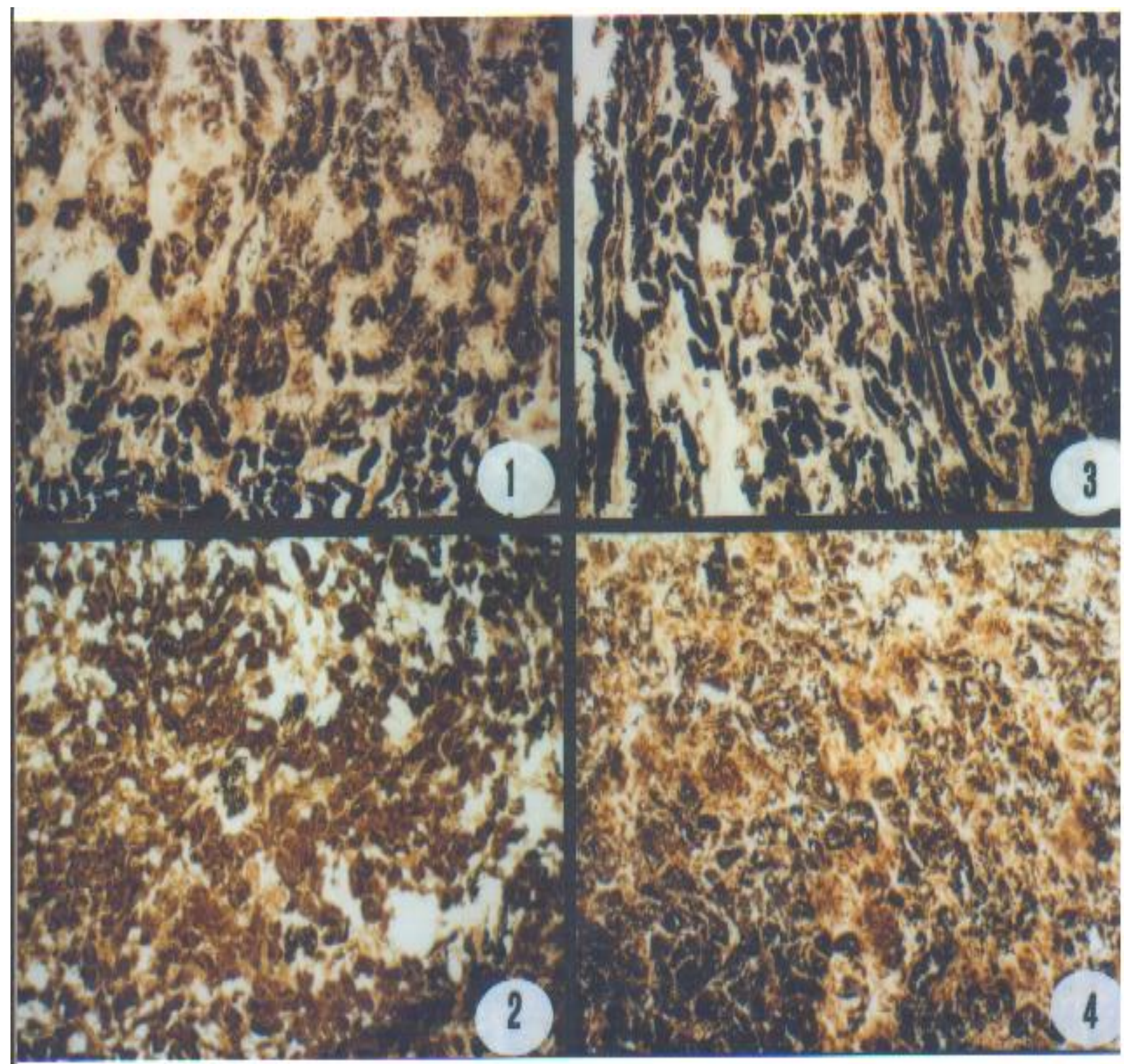

Fig.(1):

Photomicrograph of sections in the rat kidney after 1 week showing acid phosphatase enzyme activity.

1. Section of control kidney showing normal distribution of acid phosphatase enzyme activity kidney structure.

2. Section of kidney exposed to gamma rays showing increase acid phosphatase enzyme activity.

3. Section of kidney treated with pantothenic acid showing decrease acid phosphatase enzyme activity.

4. Section of kidney exposed to gamma- rays and treated with pantothenic acid showing decrease acid phosphatase enzyme activity.

(Gomori Tech., X200) 


\section{Omaima, S.Eissa et al}

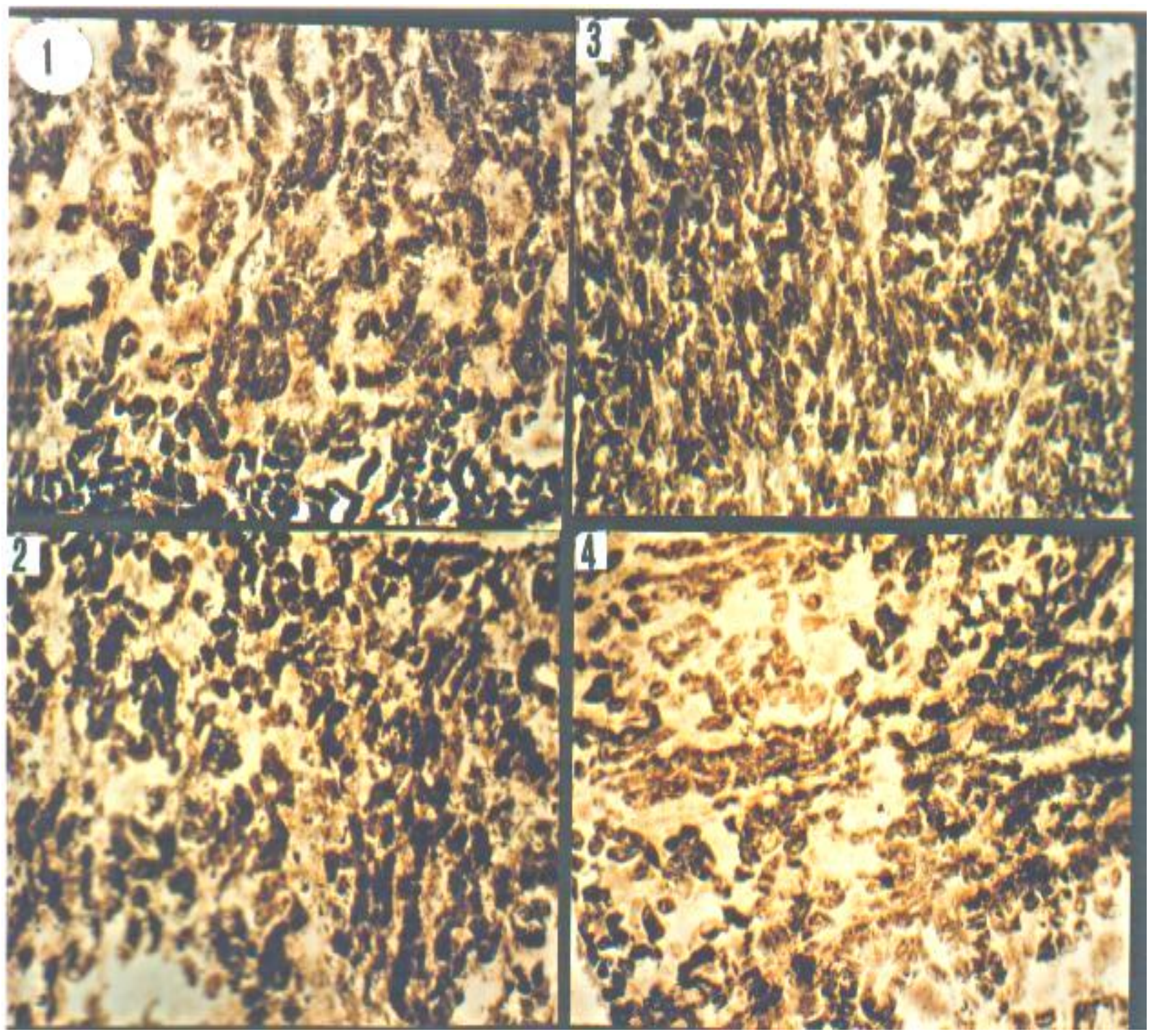

Fig.(II):

Photomicrograph of sections in the rat kidney after 4 weeks showing acid phosphatase enzyme activity.

1. Section of control kidney showing normal kidney activity.

2. Section of kidney exposed to gamma rays showing decrease acid phosphatase enzyme activity.

3. Section of kidney treated with pantothenic acid showing decrease acid phosphatase enzyme activity.

4. Section of kidney exposed to gamma- rays and treated with pantothenic acid showing decrease acid phasphatase enzyme activity.

(Gomori Tech., X200) 


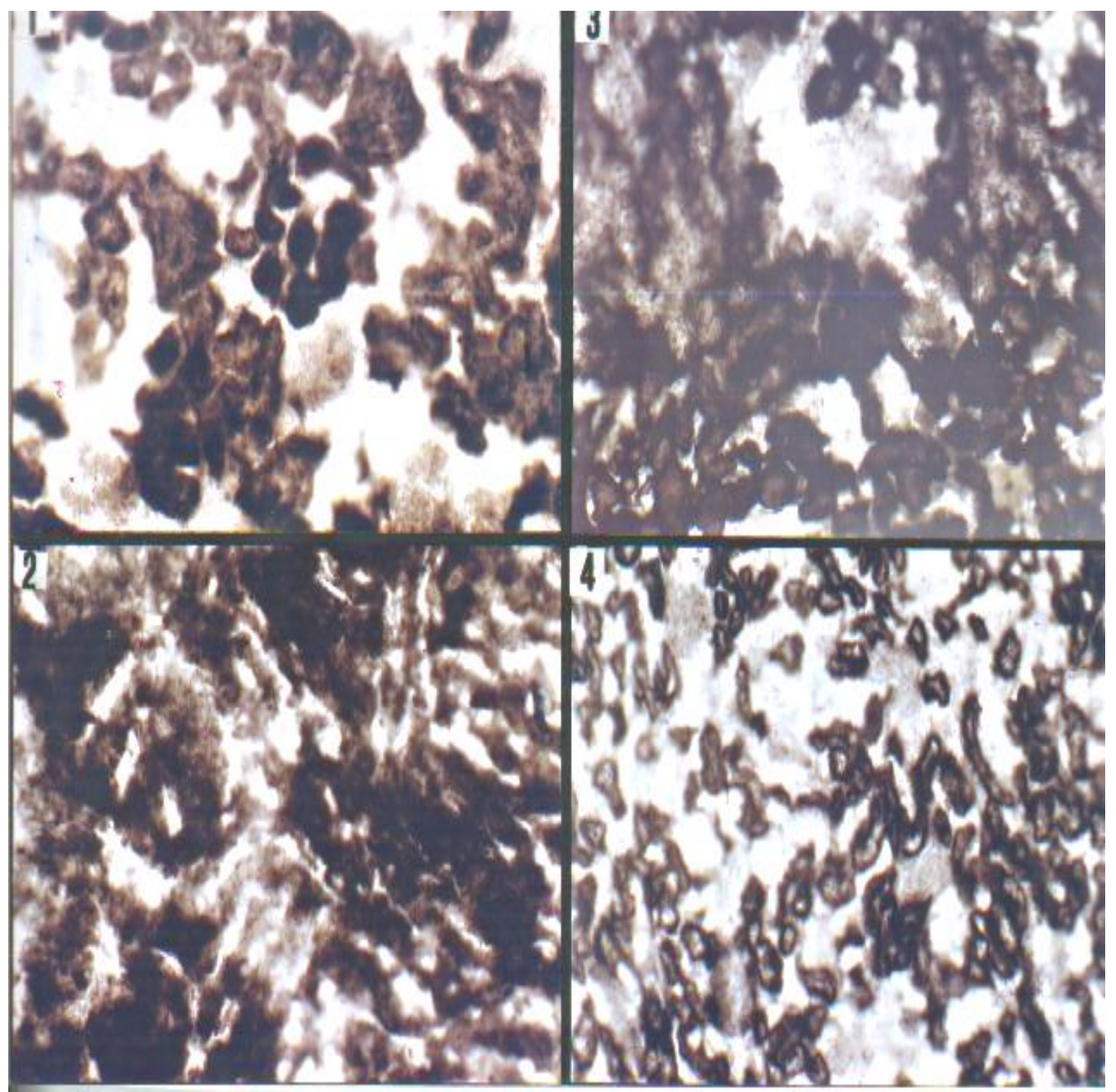

Fig.(III): Photomicrograph of sections in the rat kidney after 1 week showing alkaline phosphatase enzyme activity.

1 Section of control kidney showing normal kidney activity.

2 Section of kidney exposed to gamma rays showing decrease alkaline phosphatase enzyme activity.

3 Section of kidney treated with pantothenic acid showing decrease alkaline phosphatase enzyme activity.

4 Section of kidney exposed to gamma- rays and treated with pantothenic acid showing increase alkaline phosphatase enzyme activity.

(Modified Gomori Tech., X200) 


\section{Omaima, S.Eissa et al}

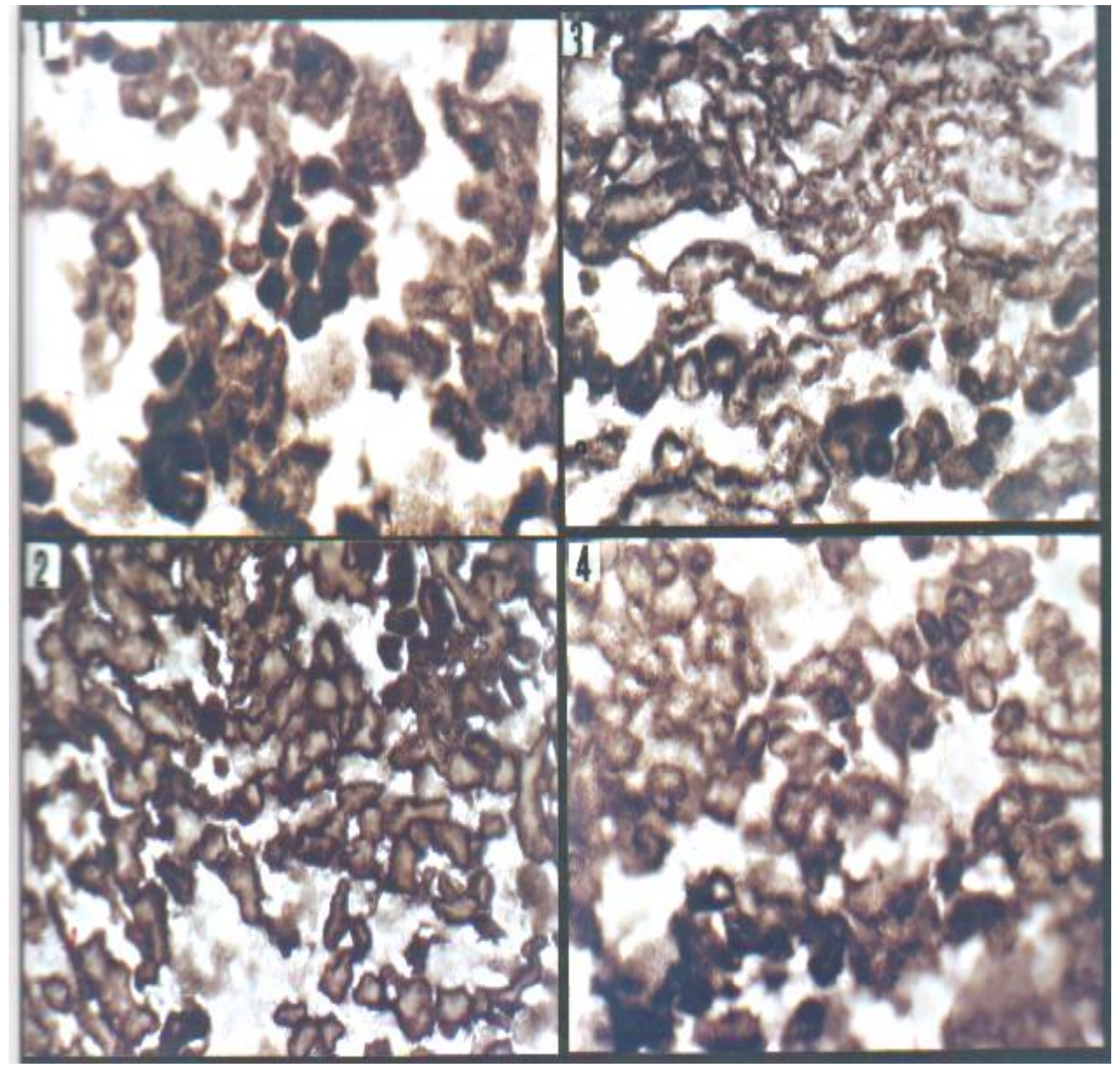

Fig.(IV): Photomicrograph of sections in the rat kidney after 4 weeks showing alkaline phosphatase enzyme activity.

1 Section of control kidney showing normal kidney activity.

2 Section of kidney exposed to gamma rays showing decrease alkaline phosphatase enzyme activity.

3 Section of kidney treated with pantothenic acid showing decrease alkaline phosphatase enzyme activity.

4 Section of kidney exposed to gamma- rays and treated with pantothenic acid showing similar to control activity.

(Modified Gomori Tech., X200) 


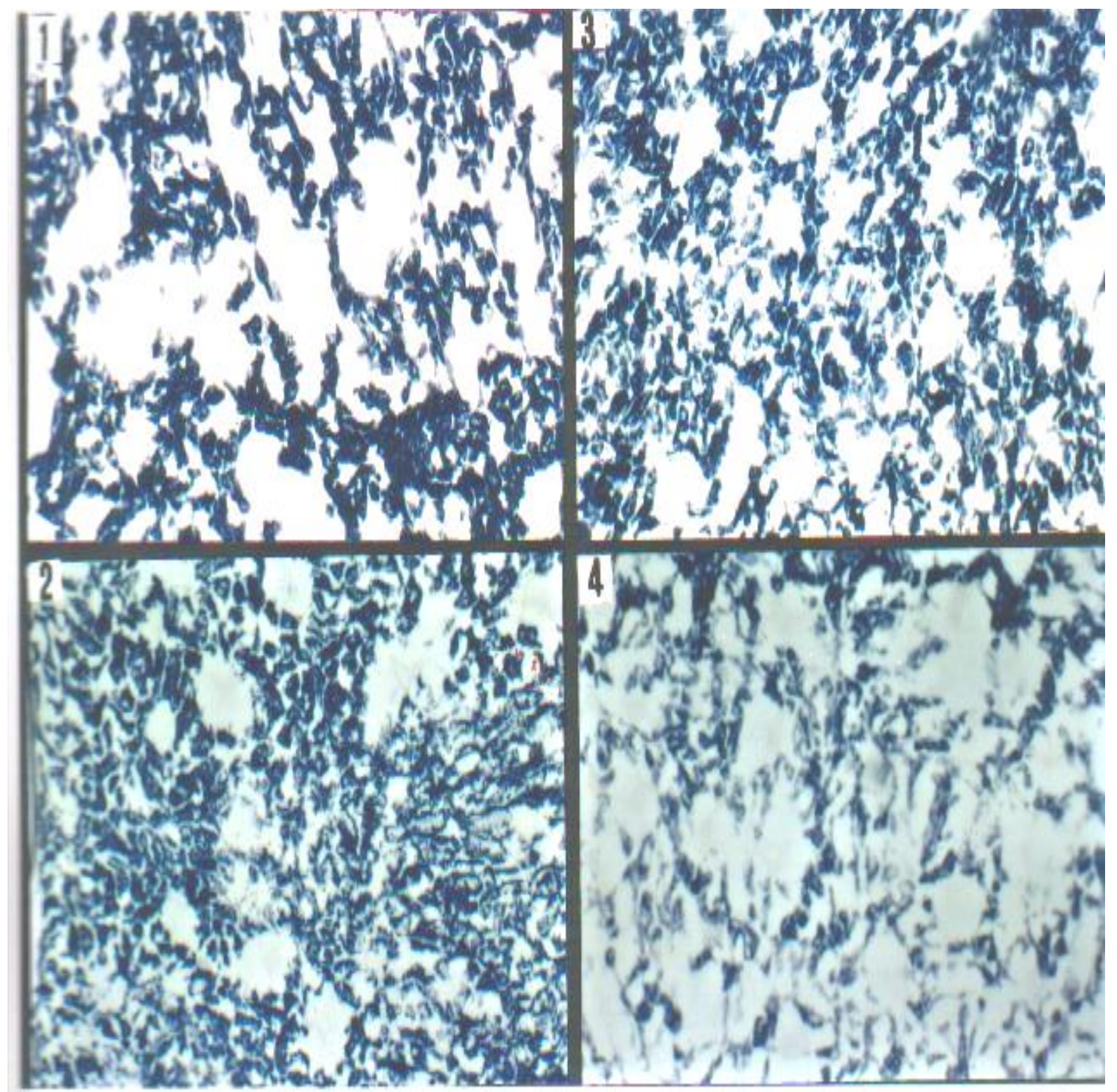

Fig.(V): Photomicrograph of sections in the rat kidney after 1 week showing succinic dehydrogenase enzyme activity.

1 Section of control kidney showing normal kidney activity.

2 Section of kidney exposed to gamma rays showing increase in the succinic dehydrogenase enzyme activity.

3 Section of kidney treated with pantothenic acid showing increase in the succinic dehydrogenase enzyme activity.

4 Section of kidney exposed to gamma- rays and treated with pantothenic acid showing increase in the succinic dehydrogenase enzyme activity.

(NachLas Tech., X200) 


\section{Omaima, S.Eissa et al}

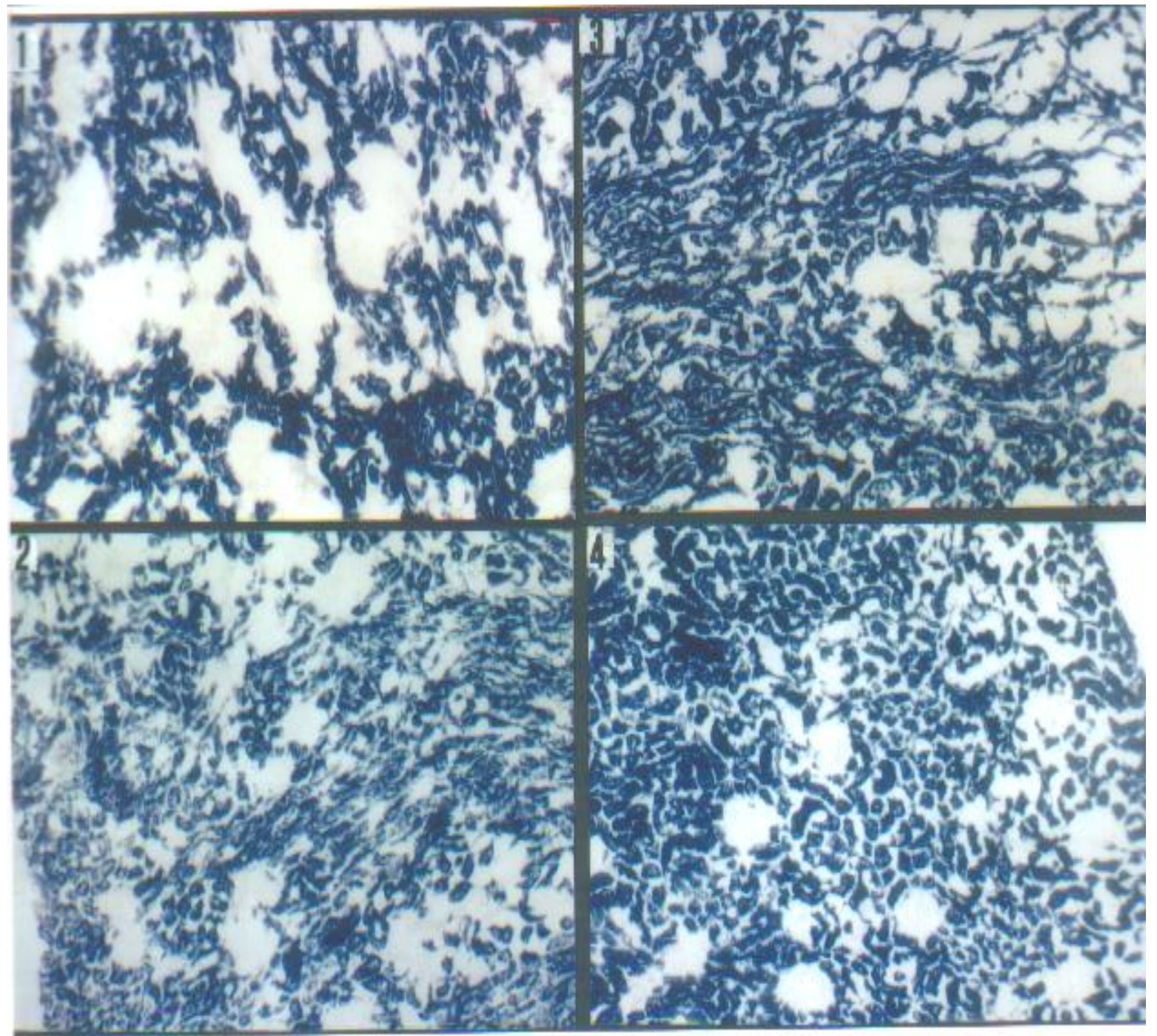

Fig.(VI): Photomicrograph of sections in the rat kidney after 4 weeks showing succinic dehydrogenase activity.

1 Section of control kidney showing normal kidney activity.

2 Section of kidney exposed to gamma rays showing decrease in the succinic dehydrogenase enzyme activity.

3 Section of kidney treated with pantothenic acid showing increase in the succinic dehydrogenase enzyme activity.

4 Section of kidney exposed to gamma- rays and treated with pantothenic acid showing increase in the succinic dehydrogenase enzyme activity.

(NachLas Tech., X200) 


\section{Histochemical studies on the role of pantothenic}

Table (1) Histochemical changes in the renal cellular structures under the effect of pantothenic acid after one week in the different groups of the study

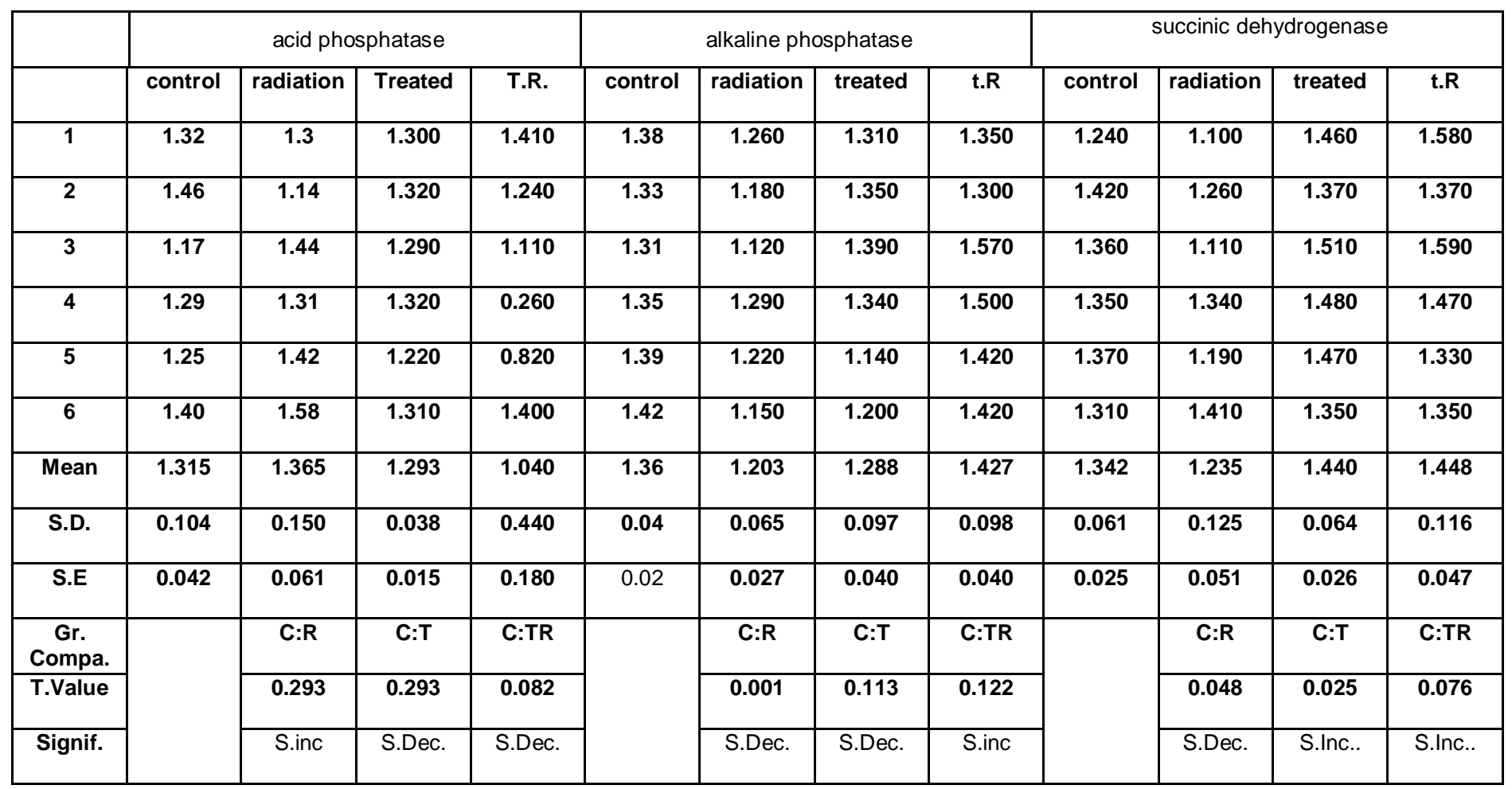

Table (2) Histochemical changes in the blood vessels under the effect of pantothenic acid after ohe week in the different groups of the study

\begin{tabular}{|c|c|c|c|c|c|c|c|c|c|c|c|c|}
\hline & \multicolumn{4}{|c|}{ acid phosphatas } & \multicolumn{4}{|c|}{ alkaline phosphatase } & \multicolumn{4}{|c|}{ succinic dehydrogenase } \\
\hline & control & radiation & treated & t.R & control & radiation & treated & t.R & control & radiation & treated & \begin{tabular}{|l|}
$t . R$ \\
\end{tabular} \\
\hline 1 & 0.34 & 0.48 & 0.54 & 0.20 & 1.42 & 1.22 & 0.52 & 0.48 & 0.70 & 0.99 & 1.47 & 0.60 \\
\hline 2 & 0.54 & 0.91 & 0.89 & 0.39 & 0.9 & 0.64 & 0.28 & 0.82 & 0.62 & 0.60 & 1.55 & \begin{tabular}{|l|}
0.53 \\
\end{tabular} \\
\hline 3 & 0.26 & 0.59 & 0.75 & \begin{tabular}{|l|}
0.96 \\
\end{tabular} & 1.36 & 0.81 & 0.36 & 0.52 & 0.79 & 0.59 & 1.66 & \begin{tabular}{|l|}
0.80 \\
\end{tabular} \\
\hline 4 & 0.28 & 0.38 & 0.48 & 0.90 & 0.5 & 0.51 & 0.24 & 0.51 & 0.49 & 0.37 & 0.99 & 0.11 \\
\hline 5 & 0.26 & 0.50 & 0.94 & \begin{tabular}{|l|}
1.04 \\
\end{tabular} & 0.89 & 0.22 & 0.38 & 0.52 & 0.62 & 0.24 & 0.87 & 0.99 \\
\hline 6 & 1.20 & 1.03 & 0.22 & \begin{tabular}{|l|}
0.41 \\
\end{tabular} & 1.32 & 0.93 & 0.6 & 0.45 & 0.10 & 0.35 & 0.86 & 0.85 \\
\hline Mean & 0.480 & 0.648 & 0.637 & \begin{tabular}{|c|}
0.65 \\
0
\end{tabular} & 1.065 & 0.722 & 0.397 & 0.550 & 0.553 & 0.523 & 1.233 & $\begin{array}{c}0.64 \\
7\end{array}$ \\
\hline S.D. & 0.368 & 0.261 & 0.274 & \begin{tabular}{|c|}
0.35 \\
7
\end{tabular} & 0.362 & 0.347 & 0.139 & 0.135 & 0.243 & 0.269 & 0.366 & $\begin{array}{c}0.31 \\
2\end{array}$ \\
\hline S.E & 0.150 & 0.106 & 0.112 & \begin{tabular}{r|}
0.14 \\
6
\end{tabular} & 0.148 & 0.142 & 0.057 & 0.055 & 0.099 & 0.110 & 0.149 & $\begin{array}{c}0.12 \\
7\end{array}$ \\
\hline Gr.compa. & & C:R & C:T & $\begin{array}{c}\text { C:T } \\
\text { R }\end{array}$ & & C:R & C:T & C:TR & & C:R & C:T & $\begin{array}{c}\text { C:T } \\
\text { R }\end{array}$ \\
\hline T.Value & & 0.045 & 0.271 & \begin{tabular}{|c}
0.26 \\
8
\end{tabular} & & 0.010 & 0.001 & 0.015 & & 0.395 & 0.001 & $\begin{array}{c}0.29 \\
7\end{array}$ \\
\hline Signif & & S.Inc. & S.Inc. & $\begin{array}{c}\text { S.In } \\
\text { c. }\end{array}$ & & S.Dec.. & S.Dec.. & S.Dec.. & & S.Dec.. & S.Inc. & $\begin{array}{c}\text { S.In } \\
\text { c. }\end{array}$ \\
\hline
\end{tabular}




\section{Omaima, S.Eissa et al}

Table (3) Histochemical changes in the renal cellular structures under the effect of pantothenic acid after four week in the different groups of the study

\begin{tabular}{|c|c|c|c|c|c|c|c|c|c|c|c|c|}
\hline & \multicolumn{4}{|c|}{ acid phosphatas } & \multicolumn{4}{|c|}{ alkaline phosphatase } & \multicolumn{4}{|c|}{ succinic dehydrogenase } \\
\hline & control & radiation & Treated & T.R. & control & radiation & treated & t.R & control & radiation & treated & t.R \\
\hline 1 & 1.32 & 1.24 & 1.4 & 1.09 & 1.38 & 1.24 & 1.09 & 1.79 & 1.24 & 1.6 & 1.36 & 1.54 \\
\hline 2 & 1.46 & 1.34 & 1.04 & 1.12 & 1.33 & 1.25 & 1.16 & 1.32 & 1.42 & 1.5 & 1.49 & 1.5 \\
\hline 3 & 1.17 & 1.37 & 1.03 & 1.25 & 1.31 & 1.14 & 1.20 & 1.31 & 1.36 & 1.39 & 1.23 & 1.36 \\
\hline 4 & 1.29 & 1.25 & 1.07 & 1.19 & 1.35 & 1.29 & 1.14 & 1.06 & 1.35 & 1.48 & 1.5 & 1.52 \\
\hline 5 & 1.25 & 0.95 & 1.16 & 1.25 & 1.39 & 1.20 & 1.38 & 1.36 & 1.37 & 1.6 & 1.45 & 1.4 \\
\hline 6 & 1.4 & 0.26 & 0.26 & 0.99 & 1.42 & 1.20 & 1.29 & 1.40 & 1.31 & 1.58 & 1.26 & 1.12 \\
\hline Mean & 1.315 & 1.068 & 0.993 & 0.990 & 1.363 & 1.220 & 1.210 & 1.373 & 1.342 & 1.525 & 1.382 & 1.407 \\
\hline S.D. & 0.104 & 0.423 & 0.385 & 0.990 & 0.041 & 0.052 & 0.107 & 0.236 & 0.061 & 0.084 & 0.117 & 0.157 \\
\hline S.E & 0.042 & 0.173 & 0.157 & 0.990 & 0.017 & 0.021 & 0.044 & 0.097 & 0.025 & 0.034 & 0.048 & 0.064 \\
\hline $\begin{array}{c}\text { Gr. } \\
\text { Compa. }\end{array}$ & & $\mathrm{C}: \mathrm{R}$ & C:T & C:TR & & C:R & C:T & C:TR & & C:R & C:T & C:TR \\
\hline T.Value & & 0.126 & 0.064 & 0.044 & & 0.001 & 0.005 & 0.459 & & 0.008 & 0.202 & 0.190 \\
\hline Signif. & & S.Dec. & S.Dec. & S.Dec. & & S.Dec. & S.Dec. & S.Inc. & & S.Inc. & S.Inc. & S.Inc. \\
\hline
\end{tabular}

Table (4) Histochemical changes in the blood vessels under the effect of pantothenic acid after four week in the different groups of the study

\begin{tabular}{|c|c|c|c|c|c|c|c|c|c|c|c|c|}
\hline & \multicolumn{4}{|c|}{ acid phosphatas } & \multicolumn{4}{|c|}{ alkaline phosphatase } & \multicolumn{4}{|c|}{ succinic dehydrogenase } \\
\hline & control & radiation & treated & t.R & control & radiation & treated & t.R & Control & Radation & Treated & TR \\
\hline 1 & 0.34 & 0.32 & 0.73 & 0.49 & 1.42 & 0.57 & 0.39 & 0.25 & 0.70 & 1.04 & 0.98 & 0.90 \\
\hline 2 & 0.54 & 0.26 & 0.46 & 0.29 & 0.9 & 0.4 & 0.07 & 0.2 & 0.62 & 0.48 & 0.65 & 0.50 \\
\hline 3 & 0.26 & 0.31 & 0.49 & 0.16 & 1.36 & 0.23 & 0.67 & 0.05 & 0.79 & 0.98 & 0.49 & 0.82 \\
\hline 4 & 0.28 & 0.70 & 0.15 & 0.06 & 0.5 & 0.01 & 0.48 & 0.25 & 0.49 & 0.98 & 0.07 & 0.82 \\
\hline 5 & 0.26 & 0.05 & 0.20 & 0.78 & 0.89 & 0.5 & 0.67 & 0.49 & 0.62 & 0.89 & 0.65 & 0.98 \\
\hline 6 & 1.20 & 0.17 & 1.01 & 0.46 & 1.32 & 0.03 & 0.33 & 0.24 & 0.10 & 0.86 & 0.45 & 0.56 \\
\hline Mean & 0.480 & 0.302 & 0.507 & 0.373 & 1.065 & 0.290 & 0.435 & 0.247 & 0.553 & 0.872 & 0.548 & 0.763 \\
\hline S.D. & 0.368 & 0.220 & 0.325 & 0.260 & 0.362 & 0.238 & 0.227 & 0.142 & 0.243 & 0.203 & 0.300 & 0.191 \\
\hline S.E & 0.150 & 0.090 & 0.133 & 0.106 & 0.148 & 0.097 & 0.093 & 0.058 & 0.099 & 0.083 & 0.122 & 0.078 \\
\hline Gr.compa. & & C:R & C:T & C:TR & & C:R & C:T & C:TR & & C:R & C:T & C:TR \\
\hline T.Value & & 0.204 & 0.394 & 0.282 & & 0.002 & 0.007 & 0.003 & & 0.024 & 0.485 & 0.033 \\
\hline Signif & & S. Dec. & S.Inc & S. Dec. & & S. Dec. & S. Dec. & S. Dec. & & S. Inc. & S.Dec & S. Inc. \\
\hline
\end{tabular}


Fig. ( 7 ): Histochemical changes in the renal cellular structures under the effect of pantothenic after one week in the different groups of the study

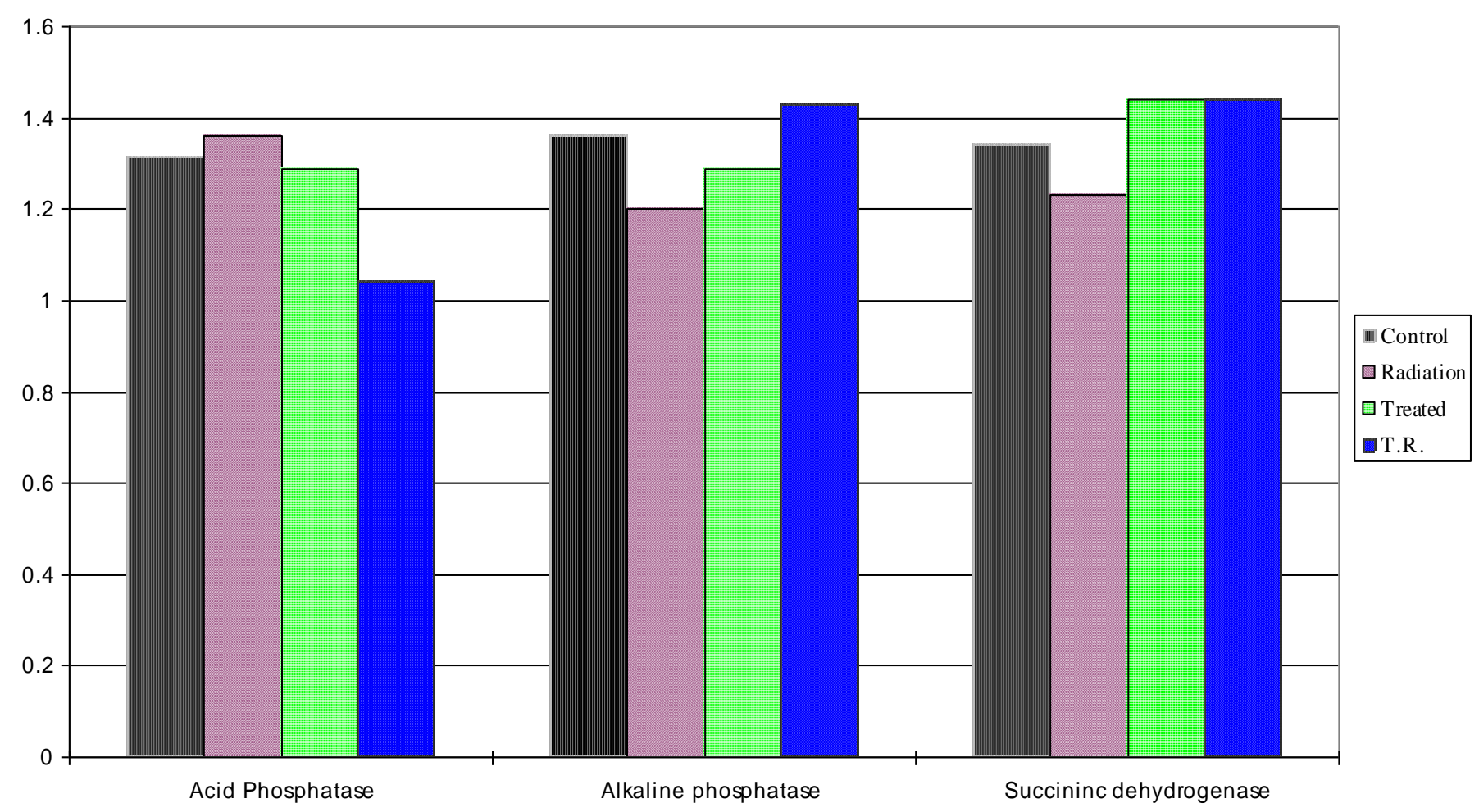

Fig. ( 8 ): Histochemical changes in the blood vessels under the effect of pantothenic acid after on week in the different groups of the study

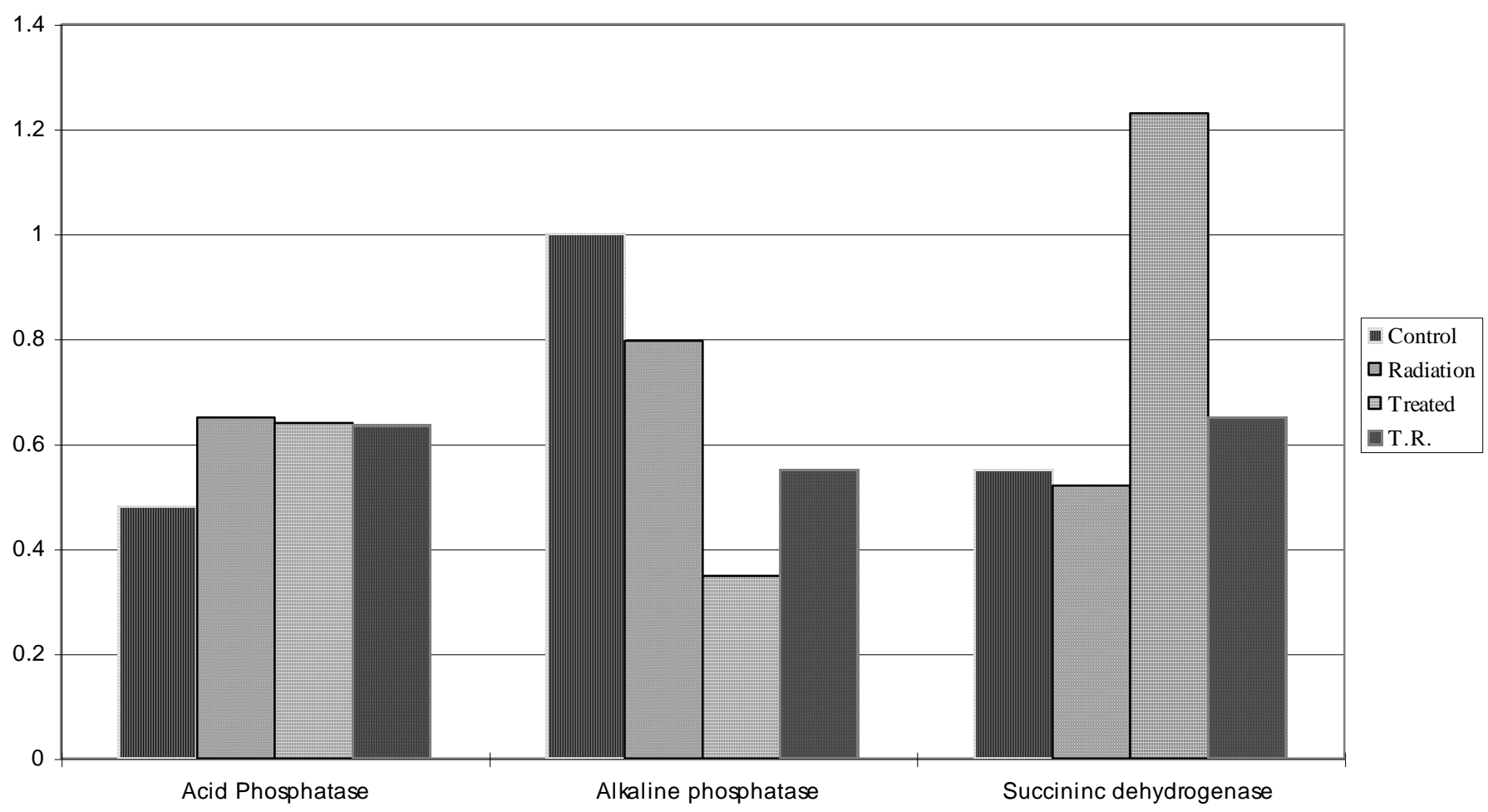




\section{Omaima, S.Eissa et al}

Fig. (9 ): Histochemical changes in the renal cellular structures under the effect of pantothenic aci after four weeks in the different groups of the study

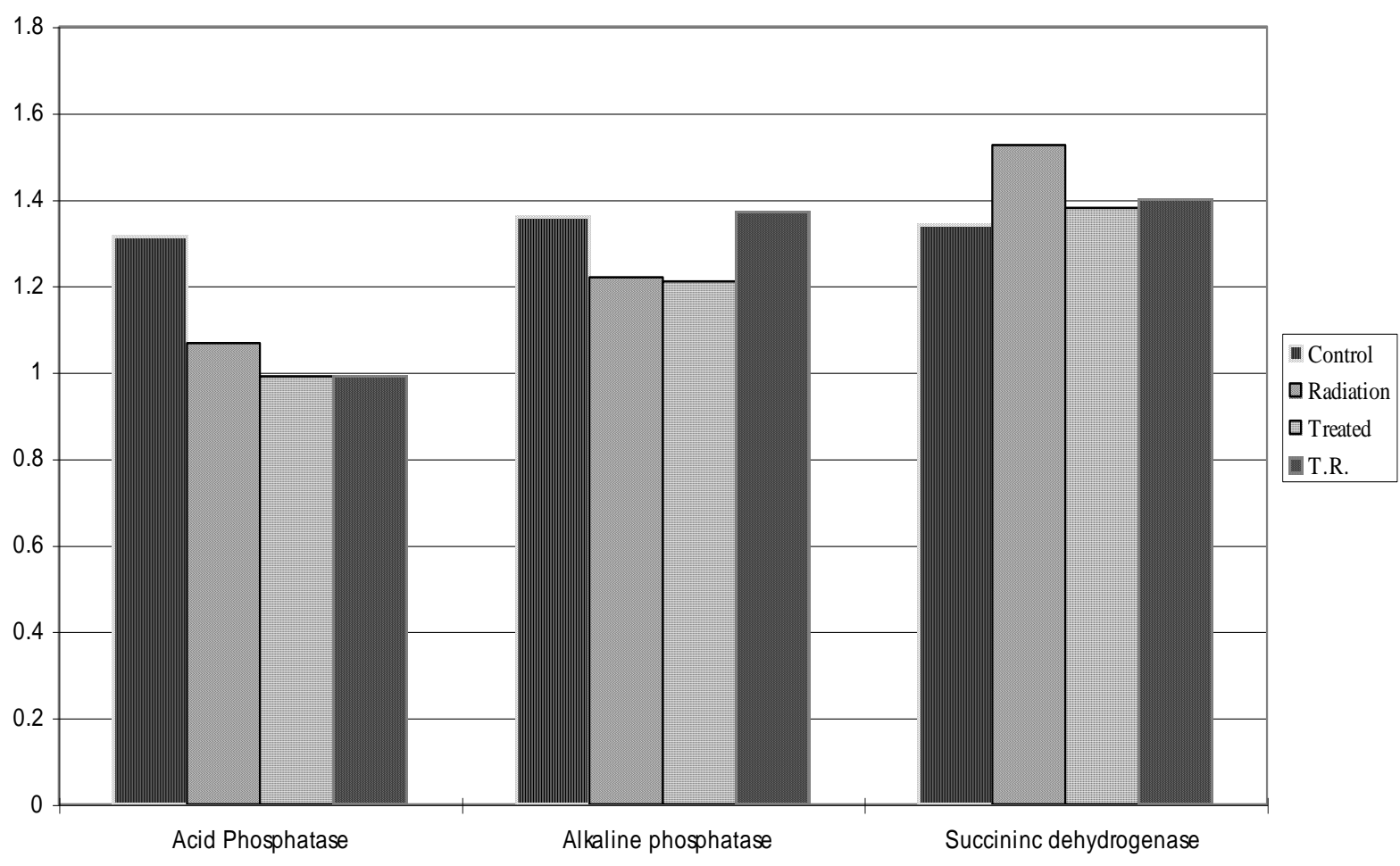

Fig. ( 10 ): Histochemical changes in the blood vessels under the effect of pantothenic acid after on week in the different groups of the study

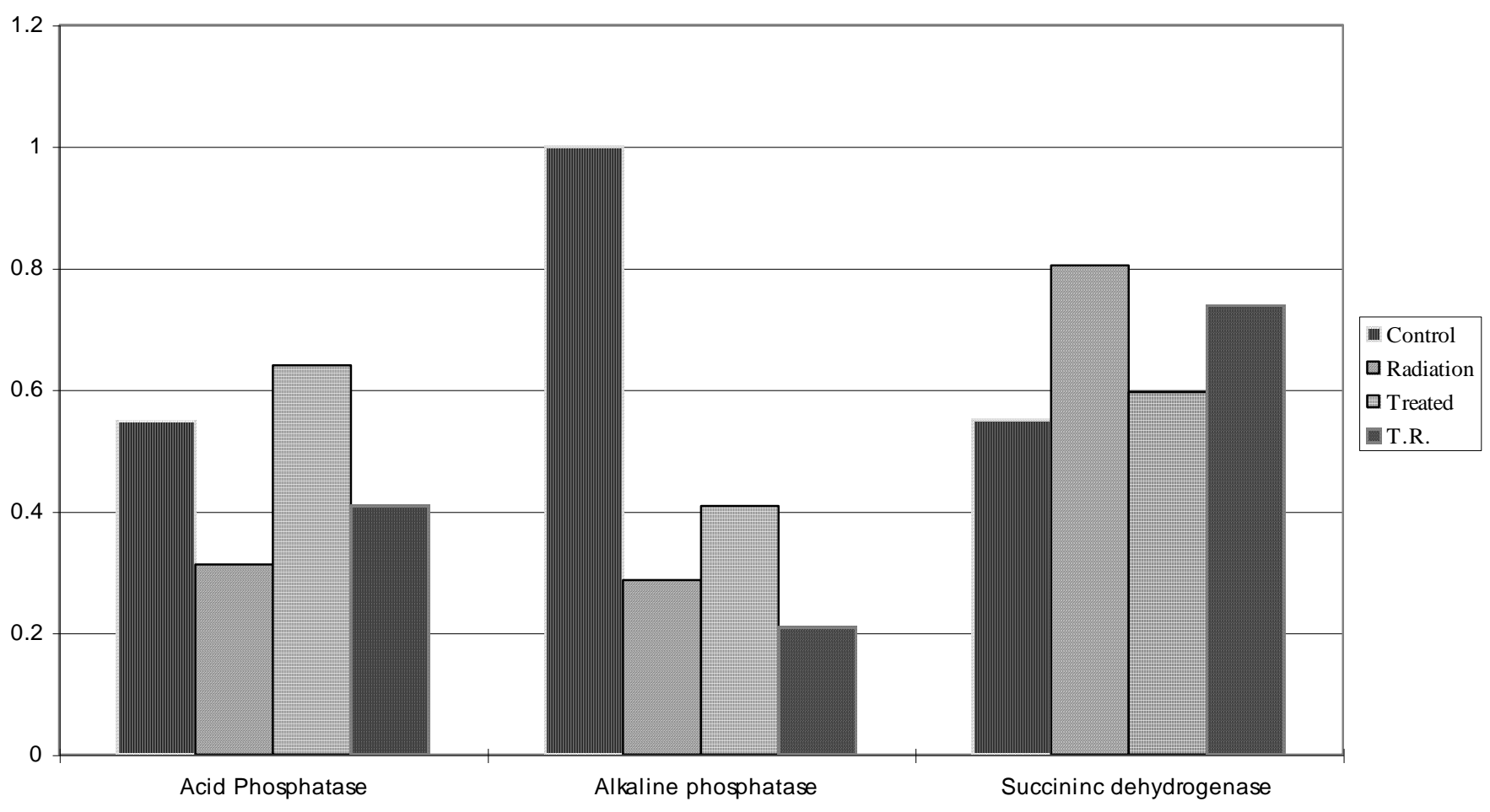




\section{دراسات هستوكيميائية على دور حمض البنتوثنيك فى تأثير الاثشعاع على الكلية}

\section{** أميمه سليمان عيسى * أشرف محمود مصطفى • المركز القومى لبحوث وتكنولوجيا الاشعاع - هيئة الطاقة الذرية * * كلية الطب - قسم الهستولوجى - جامعة الازهر}

تتاول هذا البحث دراسة التغيرات الهستوكيميائية الناتجة عن تأثثر حمض البنتوثثيك

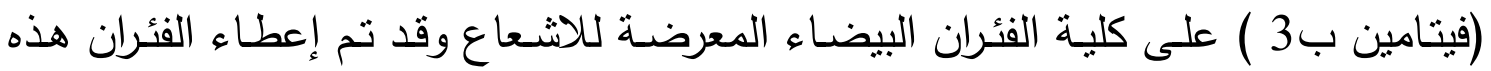
المادة على شكل جرعات يومية مقدارها (26 ملليجرام /كجم من وزن الحيوان) لمدة ستة أيام

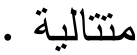

وقد أستخدم عدد 48 من إناث الجرذان البيضاء قسمت الى أربعة مجموعات حيث أعتبرت المجموعة الاولى ضابطة والمجموعة الثانية مشععة (5 جراى) والمجموعة الثالثة محقونـة بالفيتامين فقط أمسا المجوعة الرابعة فقد تم تشعيعها بالجرعة 5 جراى ثم حقنت الته

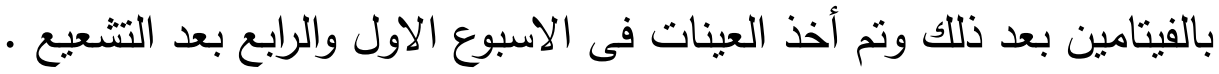

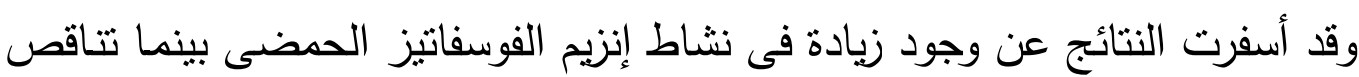
نشاط كل من إنزيم الفوسفاتيز القاعدى ونازع الهيدروجين السكسينك .

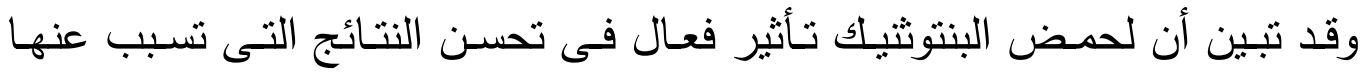

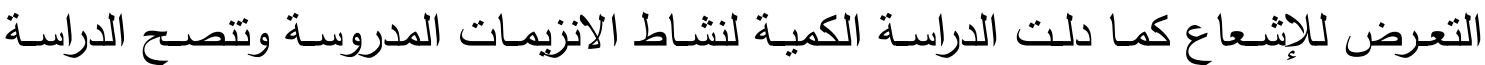
استخدامه فى تحسين نتائج الاشـعاع خاصـة على الكليـة ـ وآستتادا لهذه النتائج يمكنتـا إستخدام حمض البنتوثيك (فيتامين ب3) فى المرضى المعرضين للاشعاع والمعالجين به 